J. Dairy Sci. 92:5199-5211

doi:10.3168/jds.2009-2375

(c) American Dairy Science Association, 2009.

\title{
Milk fatty acids in dairy cows fed whole crude linseed, extruded linseed, or linseed oil, and their relationship with methane output ${ }^{1}$
}

\author{
Y. Chilliard, ${ }^{2}$ C. Martin, J. Rouel, and M. Doreau \\ INRA, UR1213 Herbivores, F63122 Saint-Genès Champanelle, France
}

\section{ABSTRACT}

This experiment studied the effect of 3 different physical forms of linseed fatty acids (FA) on cow dairy performance, milk FA secretion and composition, and their relationship with methane output. Eight multiparous, lactating Holstein cows were assigned to 1 of 4 dietary treatments in a replicated $4 \times 4$ Latin square design: a control diet (C) based on corn silage (59\%) and concentrate $(35 \%)$, and the same diet supplemented with whole crude linseed (CLS), extruded linseed (ELS), or linseed oil (LSO) at the same FA level (5\% of dietary dry matter). Each experimental period lasted 4 wk. Dry matter intake was not modified with CLS but was lowered with both ELS and LSO (-3.1 and $-5.1 \mathrm{~kg} / \mathrm{d}$, respectively) compared with C. Milk yield and milk fat content were similar for LSO and ELS but lower than for C and CLS (19.9 vs. $22.3 \mathrm{~kg} / \mathrm{d}$ and 33.8 vs. $43.2 \mathrm{~g} / \mathrm{kg}$, on average, respectively). Compared with diet C, CLS changed the concentrations of a small number of $\mathrm{FA}$; the main effects were decreases in 8:0 to $16: 0$ and increases in 18:0 and cis-9 18:1. Compared with diet C (and CLS in most cases), LSO appreciably changed the concentrations of almost all the FA measured; the main effects were decreases in FA from 4:0 to 16:0 and increases in 18:0, trans-11 16:1, all cis and trans 18:1 (except trans-11 18:1), and nonconjugated trans 18:2 isomers. The effect of ELS was either intermediate between those of CLS and LSO or similar to LSO with a few significant exceptions: increases in 17:0 iso; 18:3n-3; trans-11 18:1; cis-9, trans-11 conjugated linoleic acid; and trans-11, trans-13 conjugated linoleic acid and a smaller increase in cis-9 18:1. The most positive correlations ( $\mathrm{r}=0.87$ to 0.91 ) between milk FA concentrations and methane output were observed for saturated FA from 6:0 to 16:0 and for 10:1, and

\footnotetext{
Received May 12, 2009.

Accepted July 4, 2009

${ }^{1}$ This experiment was funded in part by Danone group, environment department, Paris, France (INRA-Danone contract B05324, 2004 "Evaluation des effets d'une supplémentation en huile ou en graine de lin sur la production de méthane et la composition en acides gras du lait chez la vache laitière").

${ }^{2}$ Corresponding author: yves.chilliard@clermont.inra.fr
}

the most negative correlations $(\mathrm{r}=-0.86$ to -0.90$)$ were observed for trans-16+cis-14 18:1; cis-9, trans-13 18:2; trans-11 16:1; and trans-12 18:1. Thus, milk FA profile can be considered a potential indicator of in vivo methane output in ruminants.

Key words: dairy cow, linseed oil, linseed, milk fatty acid

\section{INTRODUCTION}

Milk fat is an important determinant of milk nutritional quality. The saturated fatty acids (FA; mainly 12:0, 14:0, and 16:0) are considered to produce negative effects when consumed in excess, whereas others (4:0, anteiso-15:0, cis-9 18:1, 18:3n-3) have well-known or potential positive effects on human health (Parodi, 2005). In addition, cis-9,trans-11 18:2, the major isomer of conjugated linoleic acids (CLA) in ruminant milk, is anticarcinogenic and antiatherogenic in experimental animal models (Huth et al., 2006). In addition, ruminant milk fat content and composition can be extensively modified by nutritional factors, in particular fat supplementation of the diet (Shingfield et al., 2008).

There is growing interest in feeding linseed to dairy cows because of its FA profile; linolenic acid contributes to dietary n-3 FA and promotes increased CLA content while decreasing the saturated FA content of ruminant milk (review by Chilliard et al., 2007). The effects of linseed supplementation on milk yield and composition have often been studied (review by Glasser et al., 2008a). Many studies have used whole, rolled, crushed, or ground crude linseed (e.g., Kennelly, 1996; Collomb et al., 2004); linseed oil (e.g., Dhiman et al., 2000; Loor et al., 2005); and either extruded or micronized linseed (e.g., Gonthier et al., 2005; Akraim et al., 2007). However, only a few studies have directly compared different physical forms of linseed: whole versus rolled crude linseed (Kennelly, 1996) or ground crude versus extruded linseed (Gonthier et al., 2005; Akraim et al., 2007). There has been no direct comparison between supplementation with linseed oil in free form versus oil contained in linseed. Feeding linseed FA also decreases daily methane $\left(\mathrm{CH}_{4}\right)$ emissions in dairy cows (Martin et al., 2007, 2008; Beauchemin et al., 2009), which is of 
major interest given current concern about the effect of greenhouse gases on climate change and because $\mathrm{CH}_{4}$ emission from ruminants represents a loss of productive energy for the animals (Martin et al., 2009).

The objectives of this study were 1) to compare the effects on cow dairy performance and milk fatty acid secretion and composition of 4 diets based on corn silage and containing either no linseed (control) or high doses of linseed oil in 3 physical forms (whole crude linseed, extruded linseeds, or linseed oil plus linseed meal) and 2) to study the relationship between individual milk FA composition and $\mathrm{CH}_{4}$ output measured on the same cows and diets (see companion paper, Martin et al., 2008). Several studies have reported simultaneous changes in $\mathrm{CH}_{4}$ output and milk FA composition after lipid supplementation of dairy cow diet (e.g., Sauer et al., 1998; Johnson et al., 2002; Odongo et al., 2007), but no work has evaluated the use of milk FA composition to predict changes in $\mathrm{CH}_{4}$ output.

\section{MATERIALS AND METHODS}

Experimental details have been presented in a companion paper (Martin et al., 2008) and are summarized in the following.

\section{Animals, Experimental Design, and Diets}

Eight lactating, multiparous Holstein cows $(213 \pm 40$ DIM) with an average milk yield of $23.4 \pm 2.2 \mathrm{~kg} / \mathrm{d}$ and an average BW of $672 \pm 54 \mathrm{~kg}$ at the beginning of the experiment were used. Animals were blocked according to their physiological stage (4 nonpregnant cows and 4 pregnant cows, $161 \pm 99 \mathrm{~d}$ pregnant at the end of the trial) and assigned to 4 dietary treatments in a replicated $4 \times 4$ Latin square design. Each experimental period lasted 4 wk.

The treatments were 1) control diet $(\mathbf{C}), 2) \operatorname{diet} \mathrm{C}$ with whole crude linseed (CLS), 3) diet C with extruded linseed (ELS), and 4) diet C with linseed oil (LSO). The control diet consisted of $58.7 \%$ corn silage, $6.4 \%$ grass hay, and $34.9 \%$ concentrates, on a DM basis. Linseed oil was added to achieve a theoretical oil level of $5 \%$ of dietary DM and replaced part of the concentrate portion of the basal diet to obtain isoenergetic diets on an $\mathrm{NE}_{\mathrm{L}}$ basis (target value $7.1 \mathrm{MJ} / \mathrm{kg}$ of DM). In the CLS and ELS diets, proportions of whole crude and extruded linseed were calculated so that the mean oil content of these diets was similar to that of the LSO diet. Crude linseed was given as unprocessed whole seeds. Extruded linseed (INZO, Château-Thierry, France) consisted of an extruded mixture of $70 \%$ linseed and $30 \%$ wheat. In addition, $200 \mathrm{~g} / \mathrm{d}$ of a commercial mineral-vitamin premix (Galaphos, Centraliment, Aurillac, France) was added to all diets. Diets were formulated to meet the cows' requirements for maintenance and milk production (INRA, 1989) and to contain the same quantity of limiting intestinal-digestible protein (PDI system; INRA, 1989) supplied by all the feedstuffs containing linseed (linseed meal and whole crude and extruded linseeds).

Forages (hay and corn silage) were offered once daily at $0900 \mathrm{~h}$ with ad libitum access to corn silage $(10 \%$ refusals). Concentrates were allocated separately from forages in 2 equal portions at 0900 and $1600 \mathrm{~h}$ using a bucket to ensure complete consumption of the linseed. Ingredients and chemical composition of the experimental diets as consumed are given in Table 1.

Cows had free access to water throughout the experiment and were milked twice daily at 0630 and $1630 \mathrm{~h}$. All experimental procedures were conducted in accordance with French guidelines for the use of experimental animals and animal welfare (Fixant les conditions d'attribution de l'autorisation d'expérimenter, 1988).

\section{Measurements and Analyses}

Intake and Diet Composition. Feed intake and orts were measured and recorded on 5 consecutive days each week throughout the experiment to calculate DMI. Dry feed samples were pooled at the end of each experimental period for corn silage and the end of the experiment for the other feeds. These samples were ground (0.8-mm screen) and analyzed for OM, N, NDF, ADF, starch, ether extract, and total FA. Fresh samples of each feed (1 kg for corn silage, 100-200 g for other feeds) were also taken at wk 4 and stored $\left(-20^{\circ} \mathrm{C}\right.$ for corn silage and $4^{\circ} \mathrm{C}$ for other feeds) before pooling at the end of the experiment. These samples were freeze-dried, ground (0.8-mm screen), and analyzed for FA content.

Organic matter content of feeds was determined by ashing at $550^{\circ} \mathrm{C}$ for $6 \mathrm{~h}$ (AOAC, 1990). Nitrogen was analyzed by the Kjeldahl procedure (AOAC, 1990). Contents of NDF and ADF were determined by sequential procedures (Van Soest et al., 1991) after pretreatment with amylase and were expressed inclusive of residual ash. Starch was analyzed by a polarimetric method (Association Française de Normalisation, 1985). Determination of ether extract was performed after acid hydrolysis, according to AOAC (1990). Fatty acids from linseed oil were directly methylated with $2 \mathrm{~mL}$ of $0.5 \mathrm{~N}$ $\mathrm{NaOCH}_{3}$ in methanol at room temperature for $20 \mathrm{~min}$, followed by $1 \mathrm{~mL}$ of $5 \% \mathrm{HCl}$ in methanol at room temperature for 20 min. Fatty acids in feedstuffs were extracted using a 2:1 chloroform:methanol mixture. Fatty acid methyl esters were recovered in $1 \mathrm{~mL}$ of hexane. Tricosanoate (Sigma, Saint-Quentin-Fallavier, France) 
Table 2. Silage, concentrate, and total DM intake; milk production and composition; and BW in cows receiving diets supplemented or not supplemented with linseed

\begin{tabular}{|c|c|c|c|c|c|c|}
\hline \multirow[b]{2}{*}{ Item } & \multicolumn{4}{|c|}{ Diet $^{1}$} & \multirow[b]{2}{*}{ SEM } & \multirow[b]{2}{*}{$P<$} \\
\hline & $\mathrm{C}$ & CLS & ELS & LSO & & \\
\hline \multicolumn{7}{|l|}{ DMI $(\mathrm{kg} / \mathrm{d})$} \\
\hline Silage & $11.7^{\mathrm{a}}$ & $11.7^{\mathrm{a}}$ & $9.0^{\mathrm{b}}$ & $7.7^{\mathrm{c}}$ & 0.30 & 0.001 \\
\hline Concentrate & $6.8^{\mathrm{a}}$ & $6.6^{\mathrm{a}}$ & $6.4^{\mathrm{a}}$ & $5.8^{\mathrm{b}}$ & 0.16 & 0.01 \\
\hline Total & $19.8^{\mathrm{a}}$ & $19.5^{\mathrm{a}}$ & $16.7^{\mathrm{b}}$ & $14.7^{\mathrm{c}}$ & 0.31 & 0.001 \\
\hline Milk $(\mathrm{kg} / \mathrm{d})$ & $23.0^{\mathrm{a}}$ & $21.5^{\mathrm{a}}$ & $20.8^{\mathrm{ab}}$ & $18.9^{\mathrm{b}}$ & 0.74 & 0.05 \\
\hline \multicolumn{7}{|c|}{ Composition $(\mathrm{g} / \mathrm{kg})$} \\
\hline Fat & $41.1^{\mathrm{a}}$ & $45.4^{\mathrm{a}}$ & $35.3^{\mathrm{b}}$ & $32.3^{\mathrm{b}}$ & 1.48 & 0.001 \\
\hline Protein & 34.0 & 34.6 & 33.3 & 34.7 & 0.71 & $\mathrm{NS}^{2}$ \\
\hline Lactose & 48.3 & 48.2 & 48.0 & 48.6 & 0.25 & NS \\
\hline \multicolumn{7}{|l|}{ Yield (g/d) } \\
\hline Fat & $950^{\mathrm{a}}$ & $965^{\mathrm{a}}$ & $709^{\mathrm{b}}$ & $622^{\mathrm{b}}$ & 39.1 & 0.001 \\
\hline Protein & $776^{\mathrm{a}}$ & $733^{\mathrm{ab}}$ & $680^{\mathrm{bc}}$ & $644^{\mathrm{c}}$ & 24.8 & 0.01 \\
\hline Lactose & $1,111^{\mathrm{a}}$ & $1,033^{\mathrm{ab}}$ & $1,000^{\mathrm{a}, \mathrm{b}}$ & $922^{\mathrm{b}}$ & 36.9 & 0.05 \\
\hline BW (kg) & 717 & 714 & 708 & 708 & 5.4 & NS \\
\hline
\end{tabular}

${ }^{\mathrm{a}-\mathrm{C}}$ Within a row, means without a common superscript differ $(P<0.05)$.

${ }^{1} \mathrm{C}=$ control; CLS $=\operatorname{diet} \mathrm{C}$ including crude linseed; $\mathrm{ELS}=\operatorname{diet} \mathrm{C}$ including extruded linseed; LSO $=\operatorname{diet} \mathrm{C}$ including linseed oil.

${ }^{2} \mathrm{NS}: P>0.05$.

chromatograph equipped with a flame-ionization detector (Thermo Finnigan). The injector temperature was maintained at $255^{\circ} \mathrm{C}$ and the detector temperature at $260^{\circ} \mathrm{C}$. The initial oven temperature was held at $70^{\circ} \mathrm{C}$ for $1 \mathrm{~min}$, increased by $5^{\circ} \mathrm{C} / \mathrm{min}$ to $100^{\circ} \mathrm{C}$ (held for $2 \mathrm{~min}$ ), and then increased by $10^{\circ} \mathrm{C} / \mathrm{min}$ to $175^{\circ} \mathrm{C}$ (held for 40 $\min$ ) and by $5^{\circ} \mathrm{C} / \mathrm{min}$ to a final temperature of $225^{\circ} \mathrm{C}$ (held for $15 \mathrm{~min}$ ). The carrier gas was hydrogen, and the injector pressure was held constant at $158.6 \mathrm{kPa}$. Satisfactory separations of cis- and trans-18:1, nonconjugated 18:2, and CLA isomers were obtained with a single chromatographic run. Identification of 18:1, 18:2, CLA, and 18:3 isomers and odd- and branched-chain FA was as described in Loor et al. (2005). Peaks were routinely identified by comparison of retention times with FAME standards (GLC 463, Nu-Chek Prep Inc., Elysian, MN; reference mixture 47885, Supelco, Bellefonte, PA; and custom preparation of C18:1, C18:2, and CLA isomers, kindly donated by J. H. Herbein, Virginia Tech, Blacksburg, VA). Correction factors for C4:0 to C10:0 were determined on each day of analysis using a butter oil reference standard (CRM 164, Community Bureau of Reference, Brussels, Belgium). Peak integration used ChromQuest software (ChromQuest Version 3.0, ThermoQuest Corporation, San Jose, CA).

Statistical Analyses. Data on DMI and milk production were averaged on the first $5 \mathrm{~d}$ of wk 4 before statistical analysis. All data from the experiment were analyzed as a replicated $4 \times 4$ Latin square using the MIXED procedure of SAS (SAS Institute, 2000). The statistical model included cow, period, treatment (4 diets), square (one square for pregnant cows and one square for nonpregnant cows), square $\times$ treatment interaction, and residual error. Fixed effects included period, treatment, and square. Cow within square was the random effect. Overall differences between treatment means were considered significant when $P<0.05$. Differences between diets were determined using the procedure of least squares means. Correlations between milk FA profile, milk fat content, and $\mathrm{CH}_{4}$ output (measured in companion paper, Martin et al., 2008) were calculated on individual values $(\mathrm{n}=32)$. The PROC CORR and GLM procedures of SAS (SAS Institute, 2000) were used for correlation analysis. Multiple regressions to improve the prediction of $\mathrm{CH}_{4}$ output from dietary intake components, milk yield and composition, and milk FA concentrations (except 5 minor FA with mean concentrations lower than $0.02 \%$ of total FA: 22:0; 22:4n-6; trans-4 18:1; trans-5 18:1; and trans-11, trans-13 CLA) were performed using the STEPWISE procedure of SAS.

\section{RESULTS}

\section{Dairy Performance}

Compared with diet C, diet CLS had no effect on silage and concentrate intakes or total DMI $(P>0.05)$, whereas diets ELS and LSO decreased total DMI $(-3.1$ and $-5.1 \mathrm{~kg} / \mathrm{d}$, respectively; $P<0.001)$ through a decrease in corn silage intake $(-2.7$ and $-4.0 \mathrm{~kg} / \mathrm{d}$, respectively; $P<0.001$ ) (Table 2 ). The negative effect on DMI was greater for LSO than for ELS $(P<0.01)$ because of combined decreases in forage and concentrate intakes. 
Milk yield for LSO $(18.9 \mathrm{~kg} / \mathrm{d})$ was lower than for C and CLS $(22.3 \mathrm{~kg} / \mathrm{d}$ on average; $P<0.01)$, with ELS taking an intermediate value (Table 2 ). Compared with that for diet $\mathrm{C}$, milk fat content tended $(P=0.09)$ to be higher for CLS $(+4.3 \mathrm{~g} / \mathrm{kg})$ and was lower for ELS and LSO $(-7.3 \mathrm{~g} / \mathrm{kg}$ on average; $P<0.001)$. Protein and lactose contents did not vary among diets. The yield of milk fat was lower for ELS and LSO than for C and CLS $(P<0.001)$. The yields of protein and lactose were lower for ELS and LSO than for $\mathrm{C}(P<0.05)$. Body weight did not change across diets.

\section{Milk Fatty Acid Composition}

Compared with diet C, CLS changed the concentrations of a small number of FA, 8:0 to 16:0 decreased, whereas odd- and branched-chain FA did not change, except for a small decrease in 17:0 (Table 3). For the CLS diet, large increases in 18:0 and cis-9 18:1 and small increases in 20:0 and trans-16+cis-14 18:1 were observed, whereas small decreases were observed in cis9,cis-12 18:2; cis-9,cis-11 CLA (Table 4); 22:5n-3; sum of CLA; and sum of saturated and polyunsaturated FA (Table 3).

Compared with diet C (and CLS in most cases), LSO appreciably changed the concentrations of almost all the FA measured (Tables 3 and 4). Diet LSO, compared with diet C, decreased all FA (except 5:0) from 4:0 to 16:0; cis-9,cis-12 18:2; and long-chain polyunsaturated FA from 20:3n-6 to 22:5n-3. Diet LSO increased 18:0, trans-11 16:1, all cis and trans 18:1 (except for trans-11 18:1), and nonconjugated trans-18:2 isomers. However, LSO did not change CLA isomers, with the exception of a slight decrease in cis-9, cis-11 CLA (Table 4). Overall, LSO very strongly decreased saturated FA and strongly increased unsaturated FA including trans FA (Tables 3 and 4$)$.

The effect of ELS was either intermediate between those of CLS and LSO or similar to LSO with a few significant exceptions: increases in 17:0 iso; 18:3n-3; trans-11 18:1; cis-9,trans-11 CLA; and trans-11,trans-13 CLA, and a smaller increase in cis-9 18:1.

\section{Milk Fatty Acid Secretion and Desaturation Ratios}

The daily secretion of FA was not changed by CLS, except for decreases in 10:0 to 14:0, odd- and branchedchain FA, and sum of 18:1 trans and 18:2 trans (except trans-11 18:1 and cis-9,trans-11 CLA) and sharp increases in 18:0 and cis-9 18:1 (Table 5). Diet LSO, compared with diet $\mathrm{C}$, appreciably decreased the secretion of short- and medium-chain FA, slightly decreased 18:3n-3, appreciably increased cis and trans isomers of 18:1, except for cis-9 18:1 and trans-11 18:1, and did not change cis-9,trans-11 CLA. The effect of ELS was either intermediate between those of CLS and LSO or similar to LSO, except for an increase in the secretion of $18: 3 n-3$.

The transfer rates from diet to milk of $18: 3 n-3$ and C18-FA were lower with lipid-supplemented diets than with diet $\mathrm{C}$ (Table 5). The $\Delta^{9}$-desaturation ratios [product/(substrate + product)] of 5 FA were higher with LSO than with the other diets (except for 18:0 with $\operatorname{diet} \mathrm{C}$ ). There were few differences between diets C, CLS, and ELS: an increase in the 17:0 ratio for ELS and a decrease in the 18:0 ratio for CLS (Table 5).

\section{Correlations Among Milk Fatty Acid Composition, Methane Output, and Milk Fat Content}

The most positive correlations $(\mathrm{r}=0.87$ to 0.91$)$ among individual milk $\mathrm{FA}$ concentrations and $\mathrm{CH}_{4}$ output were observed for saturated FA from 6:0 to 16:0 and for 10:1, whereas $\mathrm{r}$ values between 0.83 and 0.71 were observed for 20:4n-6, 11:0, 12:1, 9:0, 15:0, 17:0, and 4:0 (Table 6). The most negative correlations ( $\mathrm{r}$ $=-0.86$ to -0.90$)$ with $\mathrm{CH}_{4}$ output were observed for trans-16+cis-14 18:1; cis-9,trans-13 18:2; trans-11 16:1; and trans-12 18:1, whereas $\mathrm{r}$ values between -0.84 and -0.72 were observed for several cis and trans isomers of 18:1, including cis-9 18:1 and trans-11,cis-15 18:2. When using sums of related FA, the correlation extremes (Figure 1) were observed for 8:0 to 16:0 ( $\mathrm{r}=$ $0.94)$ and for the sum of C18-FA $(r=-0.94)$. Almost all the correlations studied were linear, except for trans16+cis-14 18:1 and cis-9, trans-13 18:2 [r $=-0.94$ and -0.91 , respectively, with $\ln \left(\mathrm{CH}_{4}\right.$ output); Figure 1]. Correlations between $\mathrm{CH}_{4}$ output and milk FA secretions were lower than correlations between $\mathrm{CH}_{4}$ output and milk FA concentrations.

Multiple regression analysis (stepwise approach) was performed to describe $\mathrm{CH}_{4}$ output from a combination of dietary intake components, milk yield and composition, and milk FA concentrations. The best equation included 5 parameters (each significant at $P<0.01$ ):

$$
\begin{gathered}
\mathrm{CH}_{4} \text { output }(\mathrm{g} / \mathrm{d})=9.46( \pm 1.68) \times \text { milk 16:0 } \\
(\% \text { of total FA })-97.6( \pm 19.0) \times \text { milk trans-16 } \\
+ \text { cis-14 18:1 }(\% \text { of total FA })+13.3( \pm 3.43) \\
\times \text { forage intake }(\mathrm{kg} \text { of } \mathrm{DM} / \mathrm{d})-78.3( \pm 23.4) \\
\times \text { milk cis-9 14:1 }(\% \text { of total FA })+77.4( \pm 26.6) \\
\times \text { milk 18:2n- } 6(\% \text { of total FA })-21.2( \pm 72.6) \\
\left(\mathrm{n}=32, \mathrm{R}^{2}=0.953,\right. \text { root mean square } \\
\text { error }=28.8 \mathrm{~g} / \mathrm{d}) .
\end{gathered}
$$


Table 3. Milk fatty acid (FA) composition in cows receiving diets supplemented or not supplemented with linseed

\begin{tabular}{|c|c|c|c|c|c|c|}
\hline \multirow[b]{2}{*}{ Fatty acid ( $\%$ of total FA) } & \multicolumn{4}{|c|}{$\operatorname{Diet}^{1}$} & \multirow[b]{2}{*}{ SEM } & \multirow[b]{2}{*}{$P<$} \\
\hline & $\mathrm{C}$ & CLS & ELS & LSO & & \\
\hline $4: 0$ & $3.13^{\mathrm{a}}$ & $3.11^{\mathrm{a}}$ & $2.78^{\mathrm{a}}$ & $2.05^{\mathrm{b}}$ & 0.125 & 0.001 \\
\hline $5: 0$ & 0.02 & 0.03 & 0.03 & 0.02 & 0.006 & NS \\
\hline $6: 0$ & $2.24^{\mathrm{a}}$ & $2.14^{\mathrm{a}}$ & $1.64^{\mathrm{b}}$ & $1.06^{\mathrm{c}}$ & 0.069 & 0.001 \\
\hline $7: 0$ & $0.036^{\mathrm{a}}$ & $0.031^{\mathrm{a}}$ & $0.026^{\mathrm{ab}}$ & $0.013^{\mathrm{b}}$ & 0.005 & 0.05 \\
\hline $8: 0$ & $1.41^{\mathrm{a}}$ & $1.24^{\mathrm{b}}$ & $0.89^{\mathrm{c}}$ & $0.54^{\mathrm{d}}$ & 0.047 & 0.001 \\
\hline $9: 0$ & $0.039^{\mathrm{a}}$ & $0.034^{\mathrm{ab}}$ & $0.024^{\mathrm{bc}}$ & $0.013^{\mathrm{c}}$ & 0.004 & 0.01 \\
\hline 10:0 & $3.37^{\mathrm{a}}$ & $2.74^{\mathrm{b}}$ & $1.89^{\mathrm{c}}$ & $1.09^{\mathrm{d}}$ & 0.129 & 0.001 \\
\hline $10: 1$ & $0.38^{\mathrm{a}}$ & $0.30^{\mathrm{b}}$ & $0.20^{\mathrm{c}}$ & $0.12^{\mathrm{d}}$ & 0.012 & 0.001 \\
\hline 11:0 & $0.07^{\mathrm{a}}$ & $0.06^{\mathrm{a}}$ & $0.04^{\mathrm{b}}$ & $0.03^{\mathrm{b}}$ & 0.005 & 0.001 \\
\hline $12: 0$ & $4.22^{\mathrm{a}}$ & $3.22^{\mathrm{b}}$ & $2.36^{\mathrm{c}}$ & $1.52^{\mathrm{d}}$ & 0.182 & 0.001 \\
\hline $12: 1$ & $0.13^{\mathrm{a}}$ & $0.09^{\mathrm{b}}$ & $0.07^{\mathrm{bc}}$ & $0.05^{\mathrm{c}}$ & 0.010 & 0.001 \\
\hline $13: 0$ & $0.12^{\mathrm{a}}$ & $0.11^{\mathrm{a}}$ & $0.09^{\mathrm{b}}$ & $0.08^{\mathrm{b}}$ & 0.006 & 0.001 \\
\hline $14: 0$ iso & $0.15^{\mathrm{a}}$ & $0.15^{\mathrm{a}}$ & $0.10^{\mathrm{ab}}$ & $0.04^{\mathrm{b}}$ & 0.026 & 0.05 \\
\hline $14: 0$ & $12.59^{\mathrm{a}}$ & $10.80^{\mathrm{b}}$ & $8.83^{\mathrm{c}}$ & $5.88^{\mathrm{d}}$ & 0.303 & 0.001 \\
\hline $15: 0$ iso & $0.29^{\mathrm{a}}$ & $0.32^{\mathrm{a}}$ & $0.26^{\mathrm{a}}$ & $0.15^{\mathrm{b}}$ & 0.024 & 0.001 \\
\hline 15:0 anteiso & $0.64^{\mathrm{a}}$ & $0.60^{\mathrm{ab}}$ & $0.53^{\mathrm{b}}$ & $0.38^{\mathrm{c}}$ & 0.035 & 0.001 \\
\hline cis-9 14:1 & $1.33^{\mathrm{a}}$ & $0.95^{\mathrm{b}}$ & $0.97^{\mathrm{b}}$ & $0.89^{\mathrm{b}}$ & 0.071 & 0.01 \\
\hline $15: 0$ & $1.16^{\mathrm{a}}$ & $1.06^{\mathrm{a}}$ & $0.92^{\mathrm{b}}$ & $0.78^{\mathrm{c}}$ & 0.032 & 0.001 \\
\hline 16:0 iso & $0.31^{\mathrm{a}}$ & $0.34^{\mathrm{a}}$ & $0.27^{\mathrm{a}}$ & $0.12^{\mathrm{b}}$ & 0.036 & 0.01 \\
\hline $16: 0$ & $29.06^{\mathrm{a}}$ & $25.00^{\mathrm{b}}$ & $19.62^{\mathrm{c}}$ & $15.94^{\mathrm{d}}$ & 0.685 & 0.001 \\
\hline $17: 0$ iso & $0.50^{\mathrm{b}}$ & $0.47^{\mathrm{b}}$ & $0.67^{\mathrm{a}}$ & $0.47^{\mathrm{b}}$ & 0.035 & 0.01 \\
\hline trans-11 16:1 & $0.03^{\mathrm{c}}$ & $0.03^{\mathrm{c}}$ & $0.11^{\mathrm{b}}$ & $0.20^{\mathrm{a}}$ & 0.010 & 0.001 \\
\hline 17:0 anteiso & $0.50^{\mathrm{a}}$ & $0.40^{\mathrm{ab}}$ & $0.42^{\mathrm{ab}}$ & $0.34^{\mathrm{b}}$ & 0.033 & 0.05 \\
\hline cis-9 16:1 & 1.60 & 1.18 & 1.28 & 1.48 & 0.124 & NS \\
\hline cis-11 16:1 & 0.03 & 0.02 & 0.02 & 0.03 & 0.004 & NS \\
\hline $17: 0$ & $0.67^{\mathrm{a}}$ & $0.57^{\mathrm{b}}$ & $0.51^{\mathrm{c}}$ & $0.50^{\mathrm{c}}$ & 0.012 & 0.001 \\
\hline 18:0 iso & 0.03 & 0.02 & 0.05 & 0.03 & 0.011 & NS \\
\hline cis-9 17:1 & $0.19^{\mathrm{ab}}$ & $0.17^{\mathrm{b}}$ & $0.18^{\mathrm{ab}}$ & $0.20^{\mathrm{a}}$ & 0.008 & 0.05 \\
\hline $18: 0$ & $8.32^{\mathrm{c}}$ & $13.72^{\mathrm{a}}$ & $11.74^{\mathrm{ab}}$ & $11.31^{\mathrm{b}}$ & 0.730 & 0.001 \\
\hline Sum of $18: 1$ trans & $3.49^{\mathrm{b}}$ & $2.13^{\mathrm{b}}$ & $9.95^{\mathrm{a}}$ & $10.63^{\mathrm{a}}$ & 0.571 & 0.001 \\
\hline Sum of $18: 1$ cis & $18.73^{\mathrm{c}}$ & $24.84^{\mathrm{b}}$ & $25.28^{\mathrm{b}}$ & $34.22^{\mathrm{a}}$ & 0.856 & 0.001 \\
\hline Sum of $18: 2^{2}$ & $2.59^{\mathrm{c}}$ & $2.05^{\mathrm{c}}$ & $4.21^{\mathrm{b}}$ & $7.17^{\mathrm{a}}$ & 0.320 & 0.001 \\
\hline $20: 0$ & $0.06^{\mathrm{b}}$ & $0.09^{\mathrm{a}}$ & $0.06^{\mathrm{b}}$ & $0.05^{\mathrm{b}}$ & 0.007 & 0.05 \\
\hline $18: 3 n-3$ & $0.67^{\mathrm{b}}$ & $0.65^{\mathrm{b}}$ & $1.20^{\mathrm{a}}$ & $0.54^{\mathrm{b}}$ & 0.062 & 0.001 \\
\hline Sum of CLA ${ }^{3}$ & $0.84^{\mathrm{b}}$ & $0.48^{\mathrm{c}}$ & $1.33^{\mathrm{a}}$ & $0.66^{\mathrm{bc}}$ & 0.108 & 0.001 \\
\hline $22: 0$ & 0.02 & 0.02 & 0.01 & 0.01 & 0.005 & NS \\
\hline $20: 3 n-6$ & $0.06^{\mathrm{a}}$ & $0.05^{\mathrm{a}}$ & $0.03^{\mathrm{b}}$ & $0.03^{\mathrm{b}}$ & 0.004 & 0.001 \\
\hline $20: 4 n-6$ & $0.09^{\mathrm{a}}$ & $0.07^{\mathrm{a}}$ & $0.06^{\mathrm{b}}$ & $0.03^{\mathrm{c}}$ & 0.005 & 0.001 \\
\hline $20: 5 n-3$ & $0.06^{\mathrm{a}}$ & $0.05^{\mathrm{a}}$ & $0.04^{\mathrm{a}}$ & $0.02^{\mathrm{b}}$ & 0.004 & 0.001 \\
\hline $22: 4 n-6$ & $0.01^{\mathrm{a}}$ & $0.01^{\mathrm{a}}$ & $0.001^{\mathrm{b}}$ & $0.001^{\mathrm{b}}$ & 0.001 & 0.01 \\
\hline $22: 5 n-3$ & $0.09^{\mathrm{a}}$ & $0.07^{\mathrm{b}}$ & $0.06^{\mathrm{c}}$ & $0.03^{\mathrm{d}}$ & 0.005 & 0.001 \\
\hline Other FA & $0.76^{\mathrm{b}}$ & $0.56^{\mathrm{b}}$ & $1.22^{\mathrm{a}}$ & $1.27^{\mathrm{a}}$ & 0.059 & 0.001 \\
\hline Saturated & $68.95^{\mathrm{a}}$ & $66.27^{\mathrm{b}}$ & $53.74^{\mathrm{c}}$ & $42.38^{\mathrm{d}}$ & 0.794 & 0.001 \\
\hline Monounsaturated & $26.14^{\mathrm{d}}$ & $29.89^{\mathrm{c}}$ & $38.61^{\mathrm{b}}$ & $48.48^{\mathrm{a}}$ & 0.667 & 0.001 \\
\hline Polyunsaturated & $4.42^{\mathrm{c}}$ & $3.45^{\mathrm{d}}$ & $6.94^{\mathrm{b}}$ & $8.48^{\mathrm{a}}$ & 0.352 & 0.001 \\
\hline
\end{tabular}

${ }^{\mathrm{a}-\mathrm{d}}$ Within a row, means without a common superscript differ $(P<0.05)$.

${ }^{1} \mathrm{C}=$ control; $\mathrm{CLS}=\operatorname{diet} \mathrm{C}$ including crude linseed; ELS $=\operatorname{diet} \mathrm{C}$ including extruded linseed; $\mathrm{LSO}=\operatorname{diet} \mathrm{C}$ including linseed oil.

${ }^{2}$ Nonconjugated 18:2.

${ }^{3} \mathrm{CLA}=$ conjugated linoleic acid.

A simpler but very good equation was also obtained when including only the first 3 predictive parameters (each significant at $P<0.002$ ):

$$
\begin{gathered}
\mathrm{CH}_{4} \text { output }(\mathrm{g} / \mathrm{d})=-100.8( \pm 22.0) \times \text { milk } \\
\text { trans-16+cis-14 18:1 }(\% \text { of total FA })+6.78 \\
( \pm 1.75) \times \text { milk } 16: 0(\% \text { of total FA })+13.1( \pm 3.86) \\
\times \text { forage intake }(\mathrm{kg} \text { of } \mathrm{DM} / \mathrm{d})-80.1( \pm 60.9)
\end{gathered}
$$

$$
\begin{gathered}
\left(\mathrm{n}=32, \mathrm{R}^{2}=0.931, \text { root mean square error }=\right. \\
37.8 \mathrm{~g} / \mathrm{d}) .
\end{gathered}
$$

Correlations of milk FA concentrations with milk fat content were lower than with $\mathrm{CH}_{4}$ output (absolute $\mathrm{r}$ values between 0.71 and 0.78 ), positive with $6: 0$ and 8:0, and negative with cis-13 18:1; cis-9, trans-13 18:2; trans-11 16:1; trans-12 18:1; and trans-10 18:1 (Table 6). The correlation between milk fat content and $\mathrm{CH}_{4}$ output was -0.72 . 
Table 4. Milk 18:1 and 18:2 composition in cows receiving diets supplemented or not supplemented with linseed

\begin{tabular}{|c|c|c|c|c|c|c|}
\hline \multirow[b]{2}{*}{ Fatty acid ( $\%$ of total fatty acids) } & \multicolumn{4}{|c|}{$\operatorname{Diet}^{1}$} & \multirow[b]{2}{*}{ SEM } & \multirow[b]{2}{*}{$P<$} \\
\hline & $\mathrm{C}$ & CLS & ELS & LSO & & \\
\hline trans-4 18:1 & $0.013^{\mathrm{b}}$ & $0.006^{\mathrm{b}}$ & $0.031^{\mathrm{a}}$ & $0.034^{\mathrm{a}}$ & 0.004 & 0.001 \\
\hline trans-5 18:1 & $0.009^{\mathrm{b}}$ & $0.004^{\mathrm{b}}$ & $0.031^{\mathrm{a}}$ & $0.043^{\mathrm{a}}$ & 0.005 & 0.001 \\
\hline trans $-6+7+818: 1$ & $0.25^{\mathrm{b}}$ & $0.23^{\mathrm{b}}$ & $0.63^{\mathrm{a}}$ & $0.69^{\mathrm{a}}$ & 0.028 & 0.001 \\
\hline trans -9 18:1 & $0.22^{\mathrm{b}}$ & $0.18^{\mathrm{b}}$ & $0.49^{\mathrm{a}}$ & $0.43^{\mathrm{a}}$ & 0.025 & 0.001 \\
\hline trans-10 18:1 & $0.39^{\mathrm{b}}$ & $0.25^{\mathrm{b}}$ & $2.80^{\mathrm{a}}$ & $2.69^{\mathrm{a}}$ & 0.282 & 0.001 \\
\hline trans-11 18:1 & $1.49^{\mathrm{b}}$ & $0.98^{\mathrm{b}}$ & $2.75^{\mathrm{a}}$ & $1.08^{\mathrm{b}}$ & 0.301 & 0.01 \\
\hline trans-12 18:1 & $0.36^{\mathrm{c}}$ & $0.31^{\mathrm{c}}$ & $0.91^{\mathrm{b}}$ & $1.11^{\mathrm{a}}$ & 0.026 & 0.001 \\
\hline trans $-13+14$ 18:1 & $0.76^{\mathrm{c}}$ & $0.18^{\mathrm{c}}$ & $2.32^{\mathrm{b}}$ & $4.56^{\mathrm{a}}$ & 0.342 & 0.001 \\
\hline trans-16+cis-14 18:1 & $0.35^{\mathrm{d}}$ & $0.43^{\mathrm{c}}$ & $0.93^{\mathrm{b}}$ & $1.52^{\mathrm{a}}$ & 0.025 & 0.001 \\
\hline cis-9 18:1 & $17.40^{\mathrm{c}}$ & $23.51^{\mathrm{ab}}$ & $22.41^{\mathrm{b}}$ & $26.26^{\mathrm{a}}$ & 1.016 & 0.001 \\
\hline cis-10 18:1 & $0.001^{\mathrm{b}}$ & $0.001^{\mathrm{b}}$ & $0.30^{\mathrm{b}}$ & $1.44^{\mathrm{a}}$ & 0.205 & 0.001 \\
\hline cis-11 18:1 & $0.41^{\mathrm{c}}$ & $0.40^{\mathrm{c}}$ & $0.50^{\mathrm{b}}$ & $0.59^{\mathrm{a}}$ & 0.017 & 0.001 \\
\hline cis-12 18:1 & $0.28^{\mathrm{b}}$ & $0.22^{\mathrm{b}}$ & $0.25^{\mathrm{b}}$ & $0.68^{\mathrm{a}}$ & 0.047 & 0.001 \\
\hline cis-13 18:1 & $0.07^{\mathrm{c}}$ & $0.04^{\mathrm{c}}$ & $0.15^{\mathrm{b}}$ & $0.24^{\mathrm{a}}$ & 0.009 & 0.001 \\
\hline cis-15+trans-17 18:1 & $0.23^{\mathrm{b}}$ & $0.24^{\mathrm{b}}$ & $0.74^{\mathrm{b}}$ & $3.50^{\mathrm{a}}$ & 0.263 & 0.001 \\
\hline trans -9, trans -12 18:2 & $0.001^{\mathrm{b}}$ & $0.001^{\mathrm{b}}$ & $0.07^{\mathrm{a}}$ & $0.07^{\mathrm{a}}$ & 0.013 & 0.001 \\
\hline cis-9, trans-13 18:2 & $0.28^{\mathrm{c}}$ & $0.23^{\mathrm{c}}$ & $0.79^{\mathrm{b}}$ & $1.62^{\mathrm{a}}$ & 0.073 & 0.001 \\
\hline trans-11, cis-15 18:2 & $0.32^{\mathrm{c}}$ & $0.20^{\mathrm{c}}$ & $1.05^{\mathrm{b}}$ & $1.54^{\mathrm{a}}$ & 0.122 & 0.001 \\
\hline cis-9, cis-12 18:2 & $1.69^{\mathrm{a}}$ & $1.28^{\mathrm{c}}$ & $1.61^{\mathrm{ab}}$ & $1.53^{\mathrm{b}}$ & 0.042 & 0.001 \\
\hline Other nonconjugated $18: 2$ & $0.30^{\mathrm{b}}$ & $0.34^{\mathrm{b}}$ & $0.69^{\mathrm{b}}$ & $2.42^{\mathrm{a}}$ & 0.163 & 0.001 \\
\hline cis -9, trans $-11 \mathrm{CLA}^{2}$ & $0.77^{\mathrm{b}}$ & $0.44^{\mathrm{b}}$ & $1.27^{\mathrm{a}}$ & $0.65^{\mathrm{b}}$ & 0.105 & 0.001 \\
\hline cis-9, cis-11 CLA & $0.06^{\mathrm{a}}$ & $0.02^{\mathrm{b}}$ & $0.03^{\mathrm{b}}$ & $0.01^{\mathrm{c}}$ & 0.004 & 0.001 \\
\hline trans-11, trans-13 CLA & $0.006^{\mathrm{b}}$ & $0.010^{\mathrm{b}}$ & $0.019^{\mathrm{a}}$ & $0.001^{\mathrm{b}}$ & 0.003 & 0.01 \\
\hline Sum of trans $\mathrm{C} 18^{3}$ & $4.87^{\mathrm{b}}$ & $3.02^{\mathrm{b}}$ & $13.16^{\mathrm{a}}$ & $14.51^{\mathrm{a}}$ & 0.687 & 0.001 \\
\hline Sum of non-VA/RA t $18^{4}$ & $2.62^{\mathrm{c}}$ & $1.60^{\mathrm{c}}$ & $9.14^{\mathrm{b}}$ & $12.78^{\mathrm{a}}$ & 0.546 & 0.001 \\
\hline \multicolumn{7}{|c|}{${ }^{\mathrm{a}-\mathrm{d}}$ Within a row, means without a common superscript differ $(P<0.05)$. } \\
\hline \multicolumn{7}{|c|}{$\begin{array}{l}{ }^{1} \mathrm{C}=\text { control; } \mathrm{CLS}=\operatorname{diet} \mathrm{C} \text { including crude linseed; ELS }=\text { diet } \mathrm{C} \text { including extruded linseed; LSO = diet } \\
\text { including linseed oil. }\end{array}$} \\
\hline \multirow{2}{*}{\multicolumn{7}{|c|}{$\begin{array}{l}\text { including linseed oil. } \\
{ }^{2} \mathrm{CLA}=\text { conjugated linoleic acid. }\end{array}$}} \\
\hline & & & & & & \\
\hline${ }^{2} \mathrm{CLA}=$ conjugated linoleic acid. & & & & & & \\
\hline
\end{tabular}

\section{DISCUSSION}

\section{Dairy Performance}

An increase in milk yield with linseed oil supplementation has been reported [Loor et al., 2005, using $3 \%$ oil with hay-based diet; Bu et al., 2007, using $4 \%$ oil with hay/corn silage (61/39)-based diet], whereas a decrease in milk yield has been observed with extruded linseeds [Gonthier et al., 2005, using 13\% linseeds with grass/ corn (60/40) silage-based diet; Akraim et al., 2007, using $17 \%$ linseed with corn silage-based diet]. The decrease in milk yield observed in our study with both ELS and LSO was probably caused by the decreased DMI and the decreased digestibility of fiber (Martin et al., 2008) because of the high level of oil (5\% DMI) or extruded linseed (15\% DMI) intake. However, no decrease in DMI with ELS or LSO was observed in earlier studies (Gonthier et al., 2005; Loor et al., 2005; Bu et al., 2007).

The lack of negative effect of feeding CLS on DMI and milk yield is consistent with previous studies on ground crude linseed (Gonthier et al., 2005; Beauchemin et al.,
2009), although a decrease in DMI was reported with crushed linseed (Offer et al., 2001) and a decrease in milk yield was observed in 1 of 2 trials using whole crude linseed (Kennelly, 1996). The lack of negative effects with CLS in the current trial is probably because whole crude linseeds did not release FA in the rumen fluid as rapidly as ELS and LSO, and thus, rumen function was not disturbed.

Decreases in milk fat content and yield have been reported with ELS supplementation to diets with relatively high NDF contents (42-43\% of DM; Gonthier et al., 2005; Akraim et al., 2007) and were less marked than in the current study with a relatively low NDF content (31\%). Similarly, LSO supplementation decreased milk fat content and yield when added to low-NDF (as in the current study) but not to high-NDF diets (Dhiman et al., 2000; Loor et al., 2005; Flachowsky et al., 2006). A slower rate of mammary lipogenesis might have occurred as a result of adding polyunsaturated oil to a starch-rich diet (Chilliard et al., 2007; Harvatine et al., 2009), consistent with observed changes in milk FA profile, in particular the large increases in a range of trans isomers (see the following). 
Table 5. Milk fatty acid secretion, transfer rate and $\Delta^{9}$-desaturation ratio in cows receiving diets supplemented or not supplemented with linseed

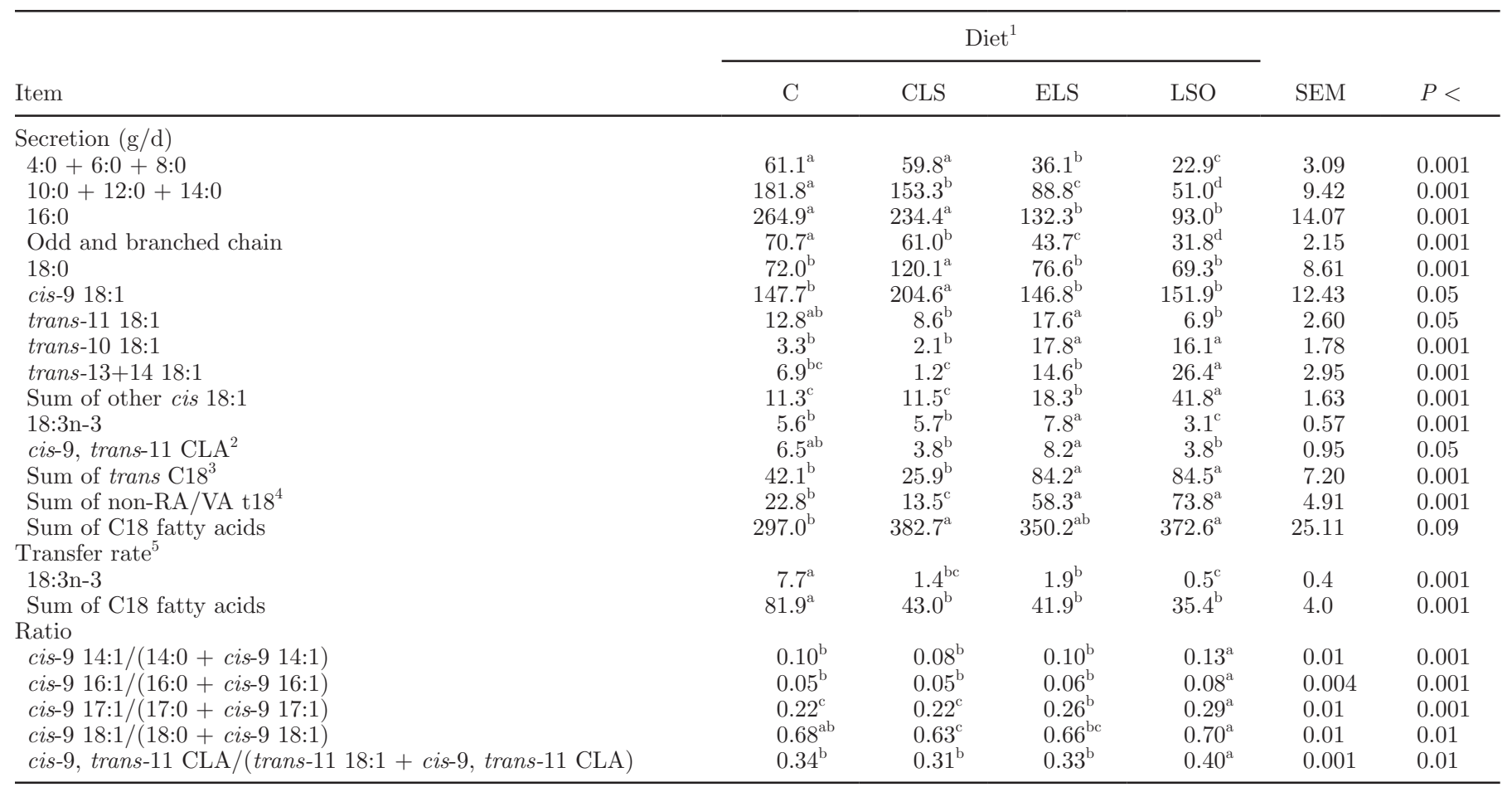

${ }^{\mathrm{a}-\mathrm{d}}$ Within a row, means without a common superscript differ $(P<0.05)$.

${ }^{1} \mathrm{C}=$ control; $\mathrm{CLS}=\operatorname{diet} \mathrm{C}$ including crude linseed; ELS $=\operatorname{diet} \mathrm{C}$ including extruded linseed; LSO $=\operatorname{diet} \mathrm{C}$ including linseed oil.

${ }^{2} \mathrm{CLA}=$ conjugated linoleic acid.

${ }^{3}$ Sum of 18:1 trans, 18:2 trans, and CLA trans.

${ }^{4}$ Sum of 18:1 trans and 18:2 trans, except trans-11 18:1 (VA) and cis-9, trans-11 CLA (RA).

${ }^{5}$ Transfer rate from diet to milk, $\%[100 \times($ milk fatty acids, $g / d) /($ fatty acid intake, $g / d)]$.

In contrast to ELS and LSO effects, CLS did not decrease milk fat content or yield, consistent with previous studies (Kennelly, 1996; Collomb et al., 2004; Gonthier et al., 2005). The lack of negative effects with CLS is probably because CLS did not release FA in the rumen fluid as rapidly as ELS and LSO, and thus, rumen function was not disturbed, as is strongly suggested by the specific changes in milk FA profile with CLS, with increases in 18:0 and cis-9 18:1 without any major increase in trans isomers (see the following). Furthermore, the high transfer rate to milk of dietary C18-FA from the CLS diet (Table 5) suggests that FA contained in whole crude linseed were equally or even more efficiently digested than those of ELS and LSO diets.

\section{Milk Fatty Acid Composition and Secretion}

The marked effect of LSO on milk FA composition (decrease in 4:0-16:0 and increase in trans 18:1 and 18:2 isomers) in the current study is consistent with other studies in which LSO was added to high-concentrate, hay-based diets (Loor et al., 2005; Flachowsky et al., 2006). In the 3 studies, a significant increase in trans-10 18:1 concentration was observed. Furthermore, trans-11 18:1 and cis-9,trans-11 CLA concentrations remained low in the current study, as in the study by Flachowsky et al. (2006), although these 2 FA increased in the study by Loor et al. (2005). The reason for this discrepancy is not clear and does not appear to be linked to corn silage, diet NDF content, or LSO dose used in the last study compared with the other two studies. A specific response to LSO in the current study (corn-silage diets) was the strong increase in milk cis-9 18:1 concentration, which was not observed in the studies with high-concentrate, hay-based diets (Loor et al., 2005; Flachowsky et al., 2006). Large increases with LSO and ELS supplementation in milk concentrations of trans-13+14 18:1; cis-9,trans-13 18:2; and trans-11,cis-15 18:2 are typical from diets rich in 18:3n-3 (review by Chilliard et al., 2007). Surprisingly, the $\Delta^{9}$-desaturation ratios of milk FA were increased only by LSO (Table 5), which could reflect an adaptation mechanism of the mammary gland to compensate for a putative increase in the melting 
Table 6. Correlations ${ }^{1}$ between milk fatty acid concentrations (\% of total fatty acids) and either methane output $\left(\mathrm{CH}_{4}, \mathrm{~g} / \mathrm{d}\right)$ or milk fat content $(\mathrm{MFC}, \mathrm{g} / \mathrm{kg})$ in cows receiving diets supplemented or not supplemented with linseed $(\mathrm{n}=32)$

\begin{tabular}{|c|c|c|c|c|c|}
\hline \multicolumn{3}{|c|}{ Positive correlations } & \multicolumn{3}{|c|}{ Negative correlations } \\
\hline Item & $\mathrm{CH}_{4}$ & MFC & Item & $\mathrm{CH}_{4}$ & MFC \\
\hline Sum 8:0-16:0² & 0.94 & & Sum of $\mathrm{C} 18$ & -0.94 & \\
\hline $16: 0$ & 0.91 & & trans-16+cis-14 18:1 & -0.90 & \\
\hline Sum 8:0-14:0 & 0.90 & & Sum of $18: 1$ cis & -0.88 & \\
\hline $8: 0$ & 0.90 & 0.71 & cis -9, trans -13 18:2 & -0.87 & -0.74 \\
\hline Sum 10:0-14:0 & 0.90 & & trans-11 16:1 & -0.86 & -0.74 \\
\hline $10: 0$ & 0.90 & & trans-12 18:1 & -0.86 & -0.74 \\
\hline $14: 0$ & 0.89 & & Sum of non-RA/VA t $18^{3}$ & -0.84 & -0.76 \\
\hline $6: 0$ & 0.88 & 0.71 & cis-13 18:1 & -0.84 & -0.78 \\
\hline $12: 0$ & 0.88 & & Sum of trans $\mathrm{C} 18$ & -0.81 & -0.72 \\
\hline $10: 1$ & 0.87 & & trans-13+14 18:1 & -0.80 & \\
\hline Sum 4:0-8:0 & 0.85 & 0.72 & Sum of $18: 1$ trans & -0.79 & \\
\hline $20: 4 n-6$ & 0.83 & & trans- $6+7+8$ 18:1 & -0.79 & \\
\hline 11:0 & 0.78 & & cis-15+trans-17 18:1 & -0.76 & \\
\hline $12: 1$ & 0.76 & & trans-11, cis-15 18:2 & -0.75 & \\
\hline 9:0 & 0.75 & & cis-9 18:1 & -0.72 & \\
\hline $15: 0$ & 0.74 & & cis-10 18:1 & -0.72 & \\
\hline $17: 0$ & 0.73 & & trans-10 18:1 & -0.66 & -0.72 \\
\hline $4: 0$ & 0.71 & & & & \\
\hline
\end{tabular}

${ }^{1}$ Only correlations $>0.7$ or $<-0.7(P<0.001)$ with either $\mathrm{CH}_{4}$ or MFC are reported.

${ }^{2} 8: 0+10: 0+12: 0+14: 0+16: 0$.

${ }^{3}$ Sum of 18:1 trans and 18:2 trans, except trans-11 18:1 (VA) and cis-9, trans-11 conjugated linoleic acid (RA).

point of FA available for triglyceride synthesis because of the simultaneous decrease in short- and mediumchain saturated FA and increase in 18:0, trans 18:1, and trans 18:2 concentrations.

The main effect of whole CLS supplementation was to appreciably increase milk $18: 0$ and cis-9 18:1 concentrations at the expense of 8:0 to 16:0 (Tables 3 and 4) consistent with previous studies using ground or rolled CLS (Kennelly, 1996; Offer et al., 2001; Collomb et al., 2004; Gonthier et al., 2005; Akraim et al., 2007). The only published study comparing whole and rolled CLS showed that whole CLS did not increase trans 18:1, whereas rolled CLS did so slightly (Kennelly, 1996), consistent with the weak effects of whole CLS on trans 18:1 in the current study. These results confirm that the distribution of whole raw seeds could allow a more complete biohydrogenation of unsaturated FA than giving free oil to dairy ruminants (Chilliard et al., 2003).

Large increases in milk concentrations of 18:3n-3; trans-10 to trans-16 18:1; and cis-9,trans-11 CLA with ELS supplementation were reported in cows receiving a corn silage-based diet (Akraim et al., 2007), as in the current study. We observed that for most FA, the effect of ELS was intermediate between those of whole CLS and LSO diets or similar to LSO (Tables 3 and 4), probably because extrusion increases the rate of oil release from the seeds into rumen fluid compared with intact seeds. However, there were some exceptions, in particular for larger-than-expected increases in milk concentrations and secretions (Table 5) of 18:3n-3; trans-11 18:1; and cis-9, trans-11 CLA. This suggests that, alongside the abundant formation of trans FA resulting from a rapid oil release from extruded seeds, some 18:3n-3 might have been protected from rumen biohydrogenation or rapidly bypassed from the rumen to the duodenum (Doreau et al., 2009), and for unknown reasons, more trans-11 18:1 than trans-13+14 18:1 was produced with ELS than with LSO (Table 5).

\section{Relationship Between Milk Fatty Acid Composition and Methane Output}

Milk FA arise from both preformed FA absorbed in the intestine and de novo synthesis from rumen acetate and butyrate, so there could be a relationship between methane and milk FA because of 1) the common biochemical pathways between methane, acetate, and butyrate in the rumen and 2) the action of dietary lipids on methane production. The conversion of pyruvate into acetate, butyrate, propionate, carbon dioxide, and hydrogen, which is in turn converted in methane, obeys a stoichiometric relationship: methane $=0.45$ acetate -0.275 propionate +0.40 butyrate (Demeyer and Van Nevel, 1975; Moss et al., 2000). Dietary FA have a negative action on methane production, especially shortand medium-chain FA and polyunsaturated 18C-FA, 
by decreasing protozoa, cellulolytic bacteria, or archaea methanogens (Martin et al., 2009). Despite this relation, the prediction of methane production through milk FA has been seldom explored, and very few experiments have measured both milk FA and methane. Vlaeminck et al. (2006) explored relationships between milk oddand branched-chain FA, used as microbial markers, and rumen volatile FA and proposed a theoretical model of prediction of methane by these FA (Vlaeminck and Fievez, 2005) using the previously mentioned stoichio- metric equation. However, in our experiment, these FA exhibited less strong correlations with methane: $\mathrm{r}=$ 0.74 and 0.73 for 15:0 and 17:0, respectively, and $\mathrm{r}=$ 0.40 to 0.50 for branched-chain FA (data not shown).

Among the $9 \mathrm{FA}$ that had the strongest negative simple correlations with cow $\mathrm{CH}_{4}$ output (Table 6), 7 (trans-16 18:1; cis-9,trans-13 18:2; trans-12 18:1; trans-13+14 18:1; trans-6+7+8 18:1; cis-15 18:1; trans11,cis-15 18:2) were biohydrogenation intermediates known to belong to a cluster of duodenal FA linked
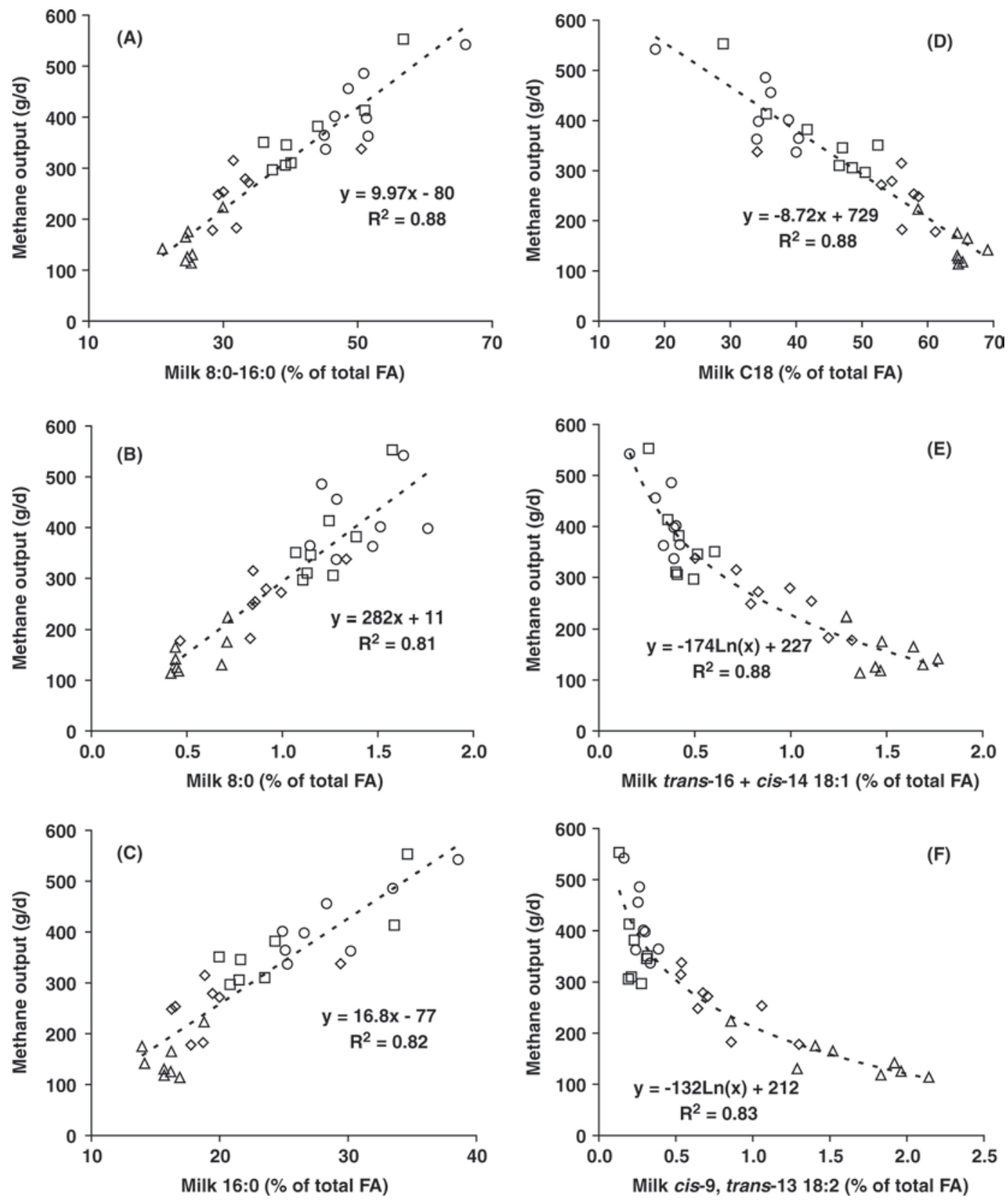

Figure 1. Relationships between methane output and selected milk fatty acid (FA) concentrations (A-F) for lactating dairy cows fed diets supplemented or not supplemented with linseed. $\bigcirc$, control; $\square$, crude linseed; $\diamond$, extruded linseed; $\Delta$, linseed oil. 
to dietary 18:3n-3 (Glasser et al., 2008b). Diets rich in polyunsaturated FA such as 18:3n-3 contribute to a decrease in $\mathrm{CH}_{4}$ through a toxic effect on protozoa and cellulolytic bacteria involved in fiber digestion and hydrogen production and possibly through a direct toxic effect on methanogens that use hydrogen for $\mathrm{CH}_{4}$ output (review by Martin et al., 2009). However, there was no correlation between dietary 18:3n-3 intake or milk 18:3n-3 concentration or secretion and $\mathrm{CH}_{4}$ output, which suggests that the effect of dietary 18:3n-3 on $\mathrm{CH}_{4}$ output is not strongly linked to the flow of $18: 3 n-3$ entering or leaving the rumen. It suggests that the action of linolenic acid on microbes might be due to biohydrogenation intermediates.

In other respects, $\mathrm{CH}_{4}$ output was positively and strongly correlated to milk 6:0 to16:0, which results mainly from mammary de novo FA synthesis, based primarily on the use of acetate produced in the rumen during fiber digestion. This positive correlation could be related directly to dietary $18: 3 \mathrm{n}-3$, which simultaneously decreases $\mathrm{CH}_{4}$ output and fiber digestion and acetate production in the rumen (see above), possibly decreasing acetate availability at the mammary level and, thus, milk FA synthesis and fat secretion with LSO and ELS diets. Furthermore, an indirect relationship could be the result of the inhibiting effects on de novo FA synthesis in mammary cells by $18: 3 n-3$ or specific trans and conjugated FA resulting from biohydrogenation of dietary 18:3n-3 or 18:2n-6 present in the basal diet (Shingfield and Griinari, 2007; Harvatine et al., 2009).

With our database, the best prediction of methane by multiple regression is excellent $\left(\mathrm{R}^{2}=0.95\right.$ vs. $\mathrm{R}^{2}$ $=0.88$ for simple regression). Among the 5 predictive variables, 3 of them could be expected: forage intake, which is an estimate of the part of the organic fermented matter that follows the acetate-methane pathway; palmitic acid, which is related to de novo synthesis, although less strongly than shorter chain FA; and trans-16+cis-14 18:1, which comprises one intermediate of linolenic acid hydrogenation. More surprising are the other 2 FA. The cis-9 14:1 isomer, which arises mainly from 14:0 desaturation (review by Bernard et al., 2008), is negatively related to $\mathrm{CH}_{4}$ output in the multiple regression. Because linseed supplementations sharply decreased 14:0 concentration (which was, thus, positively correlated to $\mathrm{CH}_{4}$ output; Table 6), it is likely that the increase in the cis-9 14:1/(14:0 + cis-9 14:1) ratio with LSO diet (Table 5) explains the entry of cis-9 14:1 in the stepwise regression. Linoleic acid is positively related to $\mathrm{CH}_{4}$ output in the multiple regression, likely as a consequence of the negative correlation between milk linoleic and linolenic acids, which is often observed with diets varying in linolenic acid intake (e.g., Loor et al.,
2005). It should be emphasized, however, that the entry of cis-9 14:1 and 18:2n-6 in the regression only slightly increased the $\mathrm{R}^{2}$ value of the prediction compared with the equation obtained with the first 3 parameters only (from 0.931 to 0.953 ).

The observed correlations between milk FA profile and cow $\mathrm{CH}_{4}$ output do not prove any causal relationship but probably reflect a chain of responses that are maximal with LSO and, to a lesser extent, ELS; that is, with diets that maximize the availability of linseed oil in the rumen and the availability of trans 18:1 and 18:2 isomers in the mammary gland and probably minimize acetate production and availability in both organs. Thus, milk FA profile can be considered to be a potential indicator of in vivo $\mathrm{CH}_{4}$ output, at least to compare different diets with large differences in 18:3n-3 content (amount consumed) and availability for the rumen ecosystem (physical form) and without other lipid sources or additives that decrease methane. It should be emphasized, however, that previous studies using other dietary supplements reported contrasting results. When feeding soybean oil, $\mathrm{CH}_{4}$ output did not change, whereas milk trans 18:1 concentration increased and 16:0 decreased (Sauer et al., 1998). When feeding monensin, $\mathrm{CH}_{4}$ output decreased, whereas milk trans 18:1 concentration increased and 16:0 decreased (Sauer et al., 1998). When feeding a mixture of cottonseed and rapeseed, $\mathrm{CH}_{4}$ output did not change, whereas milk trans 18:1 concentration increased and 16:0 decreased (Johnson et al., 2002). When feeding myristic acid, $\mathrm{CH}_{4}$ output decreased, whereas milk trans 18:1 concentration did not change and 16:0 decreased (Odongo et al., 2007). Thus, further work is needed, using a wide range of basal diets with and without a wide range of lipid supplements, to determine in what dietary conditions milk FA could be used to predict $\mathrm{CH}_{4}$ output, first in experimental and then in field conditions.

In conclusion, this study shows that a $5 \%$ supplementation of lipids from linseed to a corn silage-based diet appreciably changes cow milk FA composition, with a marked effect of the physical form of linseed oil. Inhibition of milk fat secretion, simultaneously with decreased cow $\mathrm{CH}_{4}$ output, increases with the theoretical availability of linseed oil in the rumen and the appearance of high concentrations of several trans FA in milk fat. Thus, milk FA profile can be considered a potential indicator of in vivo $\mathrm{CH}_{4}$ output; however, the validity area of the correlations that have been established is limited to diets varying in linolenic acid supply and availability. The evaluation of putative effects of using different forms of linseeds in dairy cow diets requires more long-term research on the sustainability of dairy performance, cow health and reproduction, milk quality (FA profile, micronutrients, and sensorial quality), and 
$\mathrm{CH}_{4}$ output. Further work should also consider lower levels of linseed supply and the interaction with the nature of the basal diet (pasture, grass silage, hay, or corn silage).

\section{ACKNOWLEDGMENTS}

The authors thank the skilled INRA (Saint-Genès Champanelle, France) personnel, especially D. Roux, F. Anglard, and C. Mathevon for animal care, feeding, and sampling; P. Capitan and Y. Rochette for laboratory analyses; C. Delavaud for help in regression analysis; and B. Michalet-Doreau for supporting the initial project.

\section{REFERENCES}

Akraim, F., M. C. Nicot, P. Juaneda, and F. Enjalbert. 2007. Conjugated linolenic acid (CLnA), conjugated linoleic acid (CLA) and other biohydrogenation intermediates in plasma and milk fat of cows fed raw or extruded linseed. Animal 1:835-843.

AOAC. 1990. Official Methods of Analysis. 14th ed. Assoc. Off. Anal. Chem., Arlington, VA

AOAC. 1997. Official Methods of Analysis. 16th ed. Assoc. Off. Anal. Chem, Gaithersburg, MD

Association Française de Normalisation. 1985. Aliments des animaux. Méthodes d'analyses Françaises et communautaires. Dosage de l'amidon. Méthode polarimétrique. 2nd ed. Pages 123-125 in Association Française de Normalisation, Paris, France.

Beauchemin, K. A., S. M. McGinn, C. Benchaar, and L. Holtshausen. 2009. Crushed sunflower, flax, or canola seeds in lactating dairy cow diets: Effects on methane production, rumen fermentation, and milk production. J. Dairy Sci. 92:2118-2127.

Bernard, L., C. Leroux, and Y. Chilliard. 2008. Expression and nutritional regulation of lipogenic genes in the ruminant lactating mammary gland. Adv. Exp. Med. Biol. 606:67-108.

Bu, D. P., J. Q. Wang, T. R. Dhiman, and S. J. Liu. 2007. Effectiveness of oils rich in linoleic and linolenic acids to enhance conjugated linoleic acid in milk from dairy cows. J. Dairy Sci. 90:998-1007.

Chilliard, Y., A. Ferlay, J. Rouel, and G. Lamberet. 2003. A review of nutritional and physiological factors affecting goat milk lipid synthesis and lipolysis. J. Dairy Sci. 86:1751-1770.

Chilliard, Y., F. Glasser, A. Ferlay, L. Bernard, J. Rouel, and M. Doreau. 2007. Diet, rumen biohydrogenation, cow and goat milk fat nutritional quality: A review. Eur. J. Lipid Sci. Technol. 109:828-855

Chilliard, Y., J. Rouel, and C. Leroux. 2006. Goat's alpha-s1 casein genotype influences its milk fatty acid composition and delta-9 desaturation ratios. Anim. Feed Sci. Technol. 131:474-487.

Collomb, M., H. Sollberger, U. Butikofer, R. Sieber, W. Stoll, and W. Schaeren. 2004. Impact of a basal diet of hay and fodder beet supplemented with rapeseed, linseed and sunflower seed on the fatty acid composition of milk fat. Int. Dairy J. 14:549-559.

Demeyer, D. I., and C. J. Van Nevel. 1975. Methanogenesis, an integrated part of carbohydrate fermentation and its control. Pages 366-382 in Digestion and Metabolism in the Ruminant. I. W. McDonald and A. C. I. Warner, ed. University of New England, Armidale, Australia.

Dhiman, T. R., L. D. Satter, M. W. Pariza, M. P. Galli, K. Albright, and M. X. Tolosa. 2000. Conjugated linoleic acid (CLA) content of milk from cows offered diets rich in linoleic and linolenic acid. J. Dairy Sci. 83:1016-1027.

Doreau, M., S. Laverroux, J. Normand, G. Chesneau, and F. Glasser 2009. Effect of linseed fed as rolled seeds, extruded seeds or oil on fatty acid rumen metabolism and intestinal digestibility in cows Lipids 44:53-62.

Fixant les conditions d'attribution de l'autorisation d'expérimenter. 1988. Arrêté no. 87-848 du 19 Avril 1988. J. Off. Répub. Fr. 27 Avril 1988. Statutory order No. 87-848:5707-5611. http://c-a. ifrance.com/vivisection/arrete_du_19_avril_1988.html Accessed July 31, 2008.

Flachowsky, G., K. Erdmann, L. Hüther, G. Jahreis, P. Möckel, and P. Lebzien. 2006. Influence of roughage/concentrate ratio and linseed oil on the concentration of trans-fatty acids and conjugated linoleic acid in duodenal chyme and milk fat of late lactating cows. Arch. Anim. Nutr. 60:501-511.

Glasser, F., A. Ferlay, and Y. Chilliard. 2008a. Oilseed lipid supplements and fatty acid composition of cow milk: A meta-analysis. J. Dairy Sci. 91:4687-4703.

Glasser, F., P. Schmidely, D. Sauvant, and M. Doreau. 2008b. Digestion of fatty acids in ruminants: A meta-analysis of flows and variation factors. 2. C18 fatty acids. Animal 2:691-704.

Gonthier, C., A. F. Mustafa, D. R. Ouellet, P. Y. Chouinard, R. Berthiaume, and H. V. Petit. 2005. Feeding micronized and extruded flaxseed to dairy cows: Effects on blood parameters and milk fatty acid composition. J. Dairy Sci. 88:748-756.

Harvatine, K. J., Y. R. Boisclair, and D. E. Bauman. 2009. Recent advances in the regulation of milk fat synthesis. Animal 3:4054 .

Huth, P. J., D. B. DiRienzo, and G. D. Miller. 2006. Major scientific advances with dairy foods in nutrition and health. J. Dairy Sci. 89:1207-1221.

INRA. 1989. Ruminant Nutrition: Recommended Allowances and Feed Tables. R. Jarrige, ed. INRA, John Libby Eurotext, Paris, France.

Johnson, K. A., R. L. Kincaid, H. H. Westberg, C. T. Gaskins, B. K. Lamb, and J. D. Cronrath. 2002. The effect of oilseeds in diets of lactating cows on milk production and methane emissions. J. Dairy Sci. 85:1509-1515.

Kennelly, J. J. 1996. The fatty acid composition of milk fat as influenced by feeding oilseeds. Anim. Feed Sci. Technol. 60:137-152

Loor, J. J., A. Ferlay, A. Ollier, M. Doreau, and Y. Chilliard. 2005. Relationship among trans and conjugated fatty acids and bovine milk fat yield due to dietary concentrate and linseed oil. J. Dairy Sci. 88:726-740.

Martin, C., A. Ferlay, Y. Chilliard, and M. Doreau. 2007. Rumen methanogenesis of dairy cows in response to increasing levels of dietary extruded linseeds. Pages 609-610 in 2nd Int. Symp. Energy Protein Metab. Nutr., Vichy, France, EAAP publication No.124.

Martin, C., D. P. Morgavi, and M. Doreau. 2009. Methane mitigation in ruminants: From microbe to the farm scale. Animal 3 doi:10.1017/S175173109990620

Martin, C., J. Rouel, J. P. Jouany, M. Doreau, and Y. Chilliard. 2008 Methane output and diet digestibility in response to feeding dairy cows crude linseed, extruded linseed, or linseed oil. J. Anim. Sci $86: 2642-2650$.

Moss, A. R., J. P. Jouany, and J. Newbold. 2000. Methane production by ruminants: Its contribution to global warming. Ann. Zootech. 49:231-253.

Odongo, N. E., M. M. Or-Rashid, E. Kebreab, J. France, and B. W. McBride. 2007. Effect of supplementing myristic acid in dairy cow rations on ruminal methanogenesis and fatty acid profile in milk. J. Dairy Sci. 90:1851-1858.

Offer, N. W., M. Marsden, and R. H. Phipps. 2001. Effect of oil supplementation of a diet containing a high concentration of starch on levels of trans fatty acids and conjugated linoleic acids in bovine milk. Anim. Sci. 73:533-540.

Parodi, P. W. 2005. Dairy product consumption and the risk of breast cancer. J. Am. Coll. Nutr. 24:556S-568S.

SAS Institute. 2000. SAS/STAT User's Guide: Statistics (Release 8.01.01). SAS Inst. Inc., Cary, NC.

Sauer, F. D., V. Fellner, R. Kinsman, J. K. G. Kramer, H. A. Jackson, A. J. Lee, and S. Chen. 1998. Methane output and lactation 
response in Holstein cattle with monensin or unsaturated fat added to the diet. J. Anim. Sci. 76:906-914.

Shingfield, K. J., Y. Chilliard, V. Toivonen, P. Kairenius, and D. I. Givens. 2008. Trans fatty acids and bioactive lipids in ruminant milk. Adv. Exp. Med. Biol. 606:3-65.

Shingfield, K. J., and J. M. Griinari. 2007. Role of biohydrogenation intermediates in milk fat depression. Eur. J. Lipid Sci. Technol. 109:799-816.

Van Soest, P. J., J. B. Robertson, and B. A. Lewis. 1991. Methods for dietary fiber, neutral detergent fiber, and non starch polysaccharides in relation to animal nutrition. J. Dairy Sci. 74:3538-3597.
Vlaeminck, B., and V. Fievez. 2005. Potential of milk odd- and branched-chain fatty acids to predict ruminal methanogenesis in dairy cows. Pages 393-396 in Proc. 2nd Int. Conf. Greenhouse Gases Anim. Agric., Zürich, Switzerland.

Vlaeminck, B., V. Fievez, S. Tamminga, R. J. Dewhurst, and A. Van Vuuren. 2006. Milk odd- and branched-chain fatty acids in relation to the rumen fermentation pattern. J. Dairy Sci. 89:3954-3964. 